\title{
【特 集：食品リサイクル特集】
}

\section{南但地域における可然ごみのバイオガス化と 焼却のコンバインドシステム}

\author{
高岡好和* . 河 村 公 平 ** . 角田芳 忠 ${ }^{* *}$
}

【要 旨】南但広域行政事務組合は兵庫県北部の但馬地方に位置し, 南但クリーンセンターは, 環境省 循環型社会形成推進交付金を受けた高効率原燃料回収施設として, 2013 年 5 月に竣工した（発電設備 を除く)。この施設は, 高温乾式メタン発酵によるバイオガス化設備と焼却による熱回収設備のコンバ インドシステムであり，自治体施設では国内で最初に竣工したものである。また，搬入されるごみを施 設内で機械式破砕選別する方式を採用し，住民によるごみの分別収集を必要としないという特徵がある。 さらに, FIT (再生可能エネルギー固定価格買取制度) による電力買取制度を利用したバイオガス発電 設備としても注目を集めている。

本稿では, 小規模ごみ処理施設におけるバイオマスエネルギー利活用の先進的なモデル事例として, 施設建設までの経緯，FIT のの対応，施設概要，破砕選別装置と選別ごみ，メタン発酵設備，施設全 体の物質収支と電力収支について報告する。

キーワード：メタン発酵, 固定価格買取制度, 破砕選別装置, 発電, 熱回収

\section{1. は じめに}

南但広域行政事務組合は, 図 1 に示すように, 兵庫県 北部の但馬地方に位置する養父（やぶ）市と朝来（あさ ご）市の 2 つ自治体によって構成されている。京都府 南丹市と地理的にも近く, 読み方も同じであることから 勘違いされることが多い。面積は $825.76 \mathrm{~km}^{2}$ (養父市 : $422.78 \mathrm{~km}^{2}$, 朝来市: $402.98 \mathrm{~km}^{2}$ ), 人口は 59,549 人 (養父市 : 26,338 人, 朝来市 : 33,201 人, 2013 年 2 月現 在）である ${ }^{1)}$

南但クリーンセンター（南但ごみ処理施設）は, 環境 省の循環型社会形成推進交付金を受けた高効率原燃料回 収施設 ${ }^{2}$ (交付率 1/2) として, 2013 年 5 月に竣工して

原稿受付 2013. 12.10

* 南但広域行政事務組合 南但クリーンセンター

**秼タクマエンジニアリング統轄本部 企画・開発センター 技術開発部 技術企画部

連絡先： $\bar{\top} 660-0806$ 兵庫県尼崎市金楽寺町 2-2-33 侏タクマエンジニアリング統轄本部 企画・開発センター 技術開発部 技術企画部 角田 芳忠 E-mail:kakuta@takuma.co.jp
いる（ただし，発電設備を除く）。本施設は, 高温乾式 メタン発酵によるバイオガス化設備と焼却による熱回収 設備のコンバインドシステムであり，自治体施設では国 内で最初に竣工したものである。また，搬入されるごみ を施設内で機械式破砕選別する方式を採用し，住民によ るごみの分別収集を必要としないという特徵がある。さ らに, FIT (Feed-in Tariff, 再生可能エネルギー固定価 格買取制度）による電力買取制度を利用したバイオガス 発電設備としても注目を集めている。

本稿では, 小規模ごみ処理施設におけるバイオマスエ ネルギー利活用の先進的なモデル事例として, 南但広域 行政事務組合に拈ける施設建設までの経緯, FIT への 対応, 施設概要, 破砕選別装置と選別ごみ, メタン発酵 設備について報告し, 最後に施設全体の物質収支と電力 収支を示す。これらを通じて, 廃棄物系バイオマスの利 活用への理解が進み, コンバインドシステム普及促進の 一助になれば幸いである。

\section{2. 施設建設までの経緯}

「兵庫県ごみ処理広域化計画」に基づいて, 北但地域, 


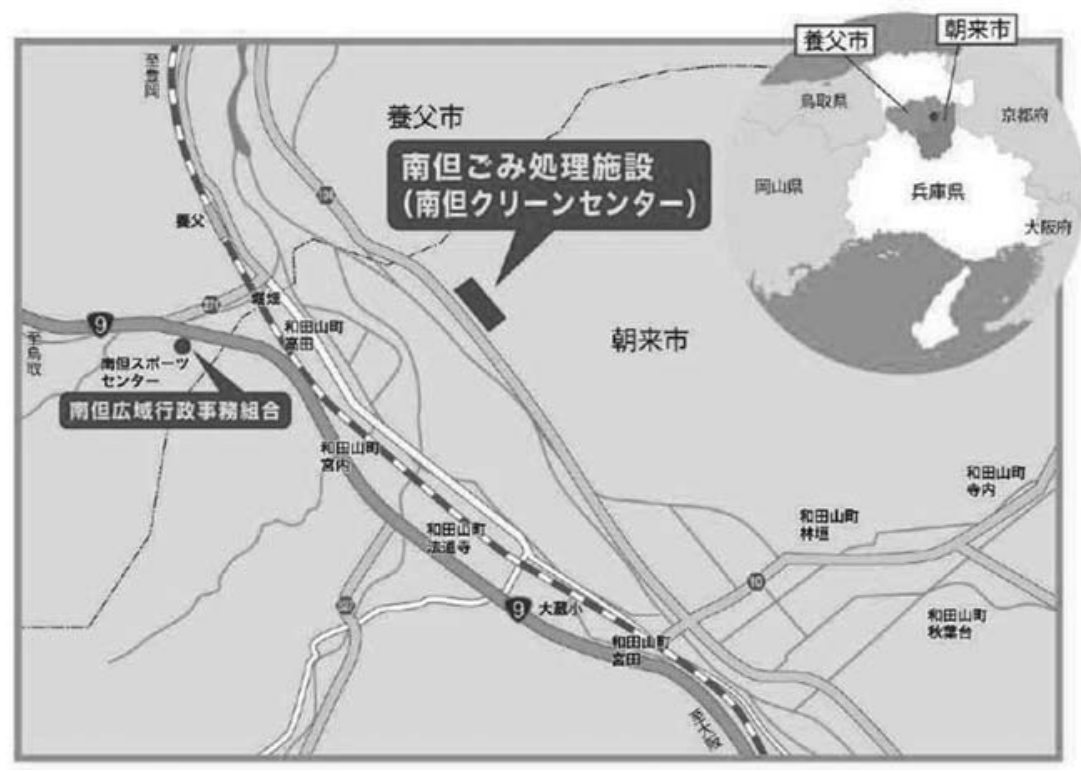

図 1 南但広域行政事務組合と南但クリーンセンターの位置図

南但地域に分ける施設整備方針が 1999 年 3 月に決定さ れた。その後, 用地最終候補地 (現在の施設設置場所) の決定 (2003 年 5 月) を経て, 第 1 次周辺地区住民説 明会 (2004 年 8 月) に打いて, 広域化の必要性・候補 地選定・施設計画案などが報告された。また, 2005 年 10〜11月には, ごみ排出量・再生利用量・最終処分量 に係る減量化，資源化の目標值が設定され，広域化後の ごみ分別区分も決定された。

1999 年 3 月以降, 固形燃料化, 炭化, 溶融方式, 熱 分解ガス化, 全量焼却方式などさまざまな処理方式の比 較検討が進められた結果, 2006 年 12 月に「バイオマス 十焼却方式」とすることが決定された。本方式は, 国内 での実績は少ないものの, 既存施設は安定して稼働して 扔り信頼性の面で問題なく, 発電の可能性や $\mathrm{CO}_{2}$ 削減 効果などを総合的に判断して, 今後の循環型社会形成お よび地球温暖化防止対策に寄与し, より周辺地区への環 境負荷軽減を図ることができるものとして南但地域に適 した方式であるとの結論を得た。

2007 年に第 2 次, 第 3 次の周辺地区住民説明会が開 催され, 2009 年 3 月には南但広域行政事務組合議会に おいて処理方式・建設地が正式承認された。2010 年に, 用地造成工事請負契約の締結, 施設建設工事請負契約が 締結された。2012 年 6 月には, 運営方式に関して, 暫 定措置ながら施設管理運営は直営とし, 運転の一部を民 間委託とする決定がなされた。2013 年に入り，3 月にリ サイクルセンターが竣工し，4月に南但クリーンセン ター (南但ごみ処理施設) が供用開始, 5 月に高効率原
燃料回収施設が発電設備を除き竣工した。

\section{FIT への対応}

FIT が 2012 年 7 月にスタートした。組合では, 環境 省廃棄物対策課に基本的な疑問点 3 件について問い合せ, 次の回答を得ている。

（1）循環型社会形成推進交付金を受けて建設した施設 でも, FIT の設備認定を受けることは可能か。

$\rightarrow$ 可能である。

（2）（2012 年 7 月当時）提示されているメタン発酵ガ ス化バイオマスには, 下水污泥と家畜䨢尿しか規 定されていないが，一般廃棄物を原料とするメ夕 ン発酵でも対象となるか。

$\rightarrow$ 対象となる。

（3）経済産業省の補助を受けて整備した施設では調達 価格を減額する措置がとられる場合があるが，環 境省の交付金を受けて整備した施設でも同様の措 置がとられる予定はあるか。

$\rightarrow$ 減額措置をとる考えはない。

また, 2012 年 12 月には, 経済産業省新エネルギー課 から「バイオガス発電設備の範囲等について」という通 達が出され, 発電設備はメタン発酵槽以降とされた。そ の後, 近畿経済産業局エネルギー対策課に, 発電設備認 定申請書を提出し受理された。

2013 年 2 月には, 関西電力豊岡営業所から, 「認定発 電設備を分離せずに発電した場合には, 既設扱いになら 
ないか経済産業省に確認してほしい」との問い合せが あった。近畿経済産業局エネルギー対策課からの回答は 次のとおりである。

$\rightarrow$ 認定発電設備を分離せずに発電し, 認定発電設備以 外に電力を供給した場合には, その後分離しても既 設の転用となり, 固定価格買取制度の適用対象とは ならない。

つまり, 認定発電設備の分離工事が終了するまでは発 電できないということである。組合では, 関西電力に近 畿経済産業局からの回答を報告し, 分離工事完了後に発 電を開始することを伝えた。

その後, 2013 年 3 月には, 経済産業省から再生可能 エネルギー発電設備の認定を受け, 発電設備分離工事に 係る工事請負契約を締結している。さらに7月には, 関 西電力と電気需給契約, 給電申合書を締結 (発電設備 : バイオガスエンジン $720 \mathrm{kVA}$ ) し, 系統連係を行い試 運転を開始した。8月末に発電設備分離工事が完了し設 備の引き渡しを受け, 9 月から発電設備の本格運転を開 始している。

\section{4. 南但クリーンセンター施設概要}

\section{1 主要設備と概略仕様}

図 2 に南但クリーンセンターの施設全体の配置図を示 す。建築物としては, 高効率原燃料回収施設, リサイク ルセンター, ストックヤード棟がある。高効率原燃料回 収施設には, 熱回収設備 (焼却設備) とバイオマス設備 (メタン発酵設備) が含まれ, その施設外観は図 3 およ び図 4 の写真で示されている。図 4 は, 図 3 の奥の山側 から見た外観である。また、リサイクルセンターには, 計量室を兼ねた管理事務所, 会議室などの管理諸室が含 まれている。高効率原然料回収施設における熱回収設備 とバイオマス設備の概略設計仕様は次のとおりである ${ }^{3)}$ 。

・熱回収設備:

形式； ストーカ式焼却炉

処理能力; 43 ton $/$ 日 $\times 1$ 系列 $(24 \mathrm{~h}$ 運転)

低位発熱量；9,000 kJ/kg

・ バイオマス設備 :

形式; 高温乾式メタン発酵

処理能力; 36 ton $/$ 日 $\times 1$ 系列 $(24 \mathrm{~h}$ 運転, 前処

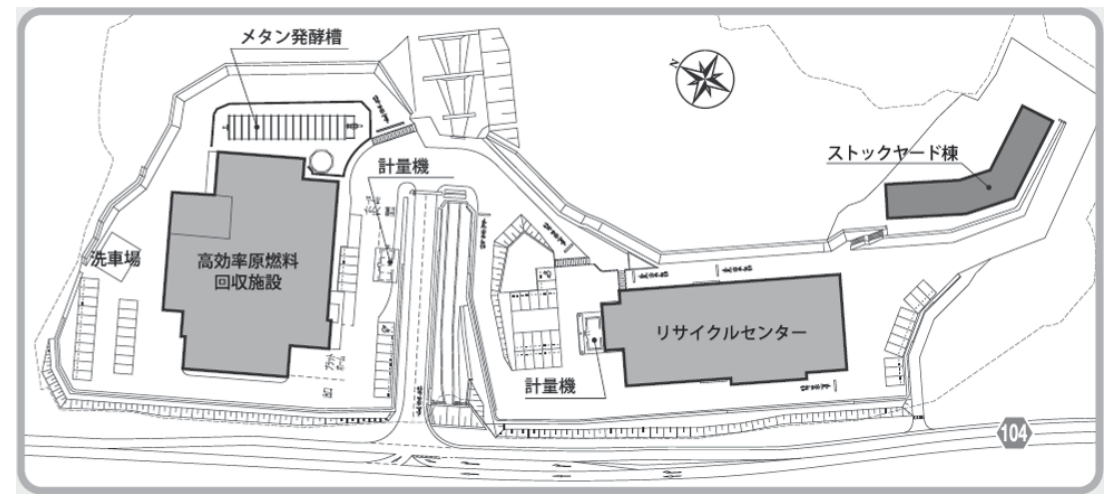

図 2 施設全体配置図

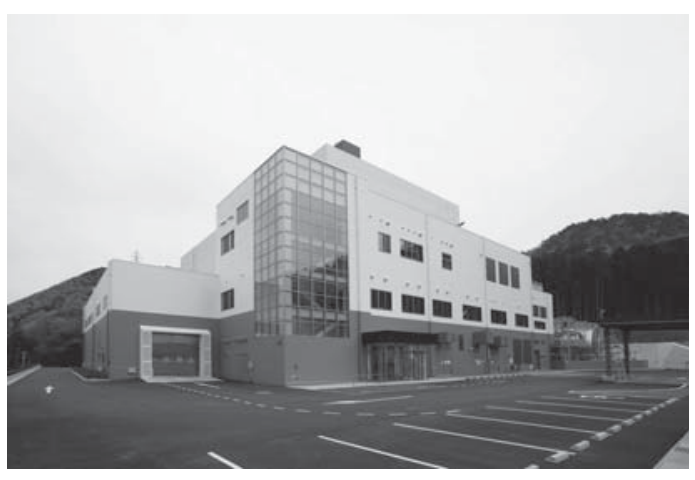

図 3 施設外観写真-1

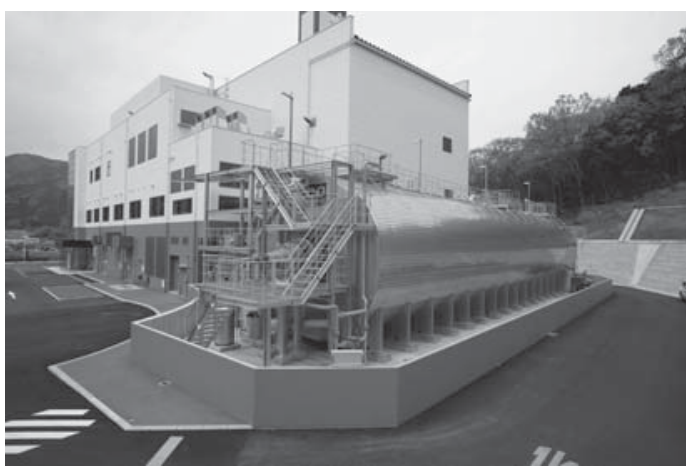

図 4 施設外観写真-2 
理設備入口にて)

ガス回収量（メタン濃度 50\% 換算）；

$3,000 \mathrm{~m}^{3}{ }_{\mathrm{N}}-\mathrm{dry} /$ 日以上

$150 \mathrm{~m}^{3}{ }_{\mathrm{N}}-\mathrm{dry} / \mathrm{ton}$ 以上

なお、リサイクルセンターの処理能力は, 17 ton/日 (5 h 運転) となっており, 回転式破砕機と選別設備, 缶類や容器包装類を対象とする資源化設備によって構成 されている。

\section{2 高効率原燃料回収施設の処理フロー}

図 5 に, 高効率原燃料回収施設を構成する熱回収設備 (焼却設備) とバイオマス設備（メタン発酵設備）の処 理フローを示す。バイオマス設備の右側部分に示してい るメタン発酵槽以降の破線で囲まれた範囲が，FITの 対象となる認定発電設備である。ここでは, バイオマス 設備と熱回収設備との相互関連の部分についてのみ記述 する。

施設への搬入可燃ごみは，一旦受入ピットに貯留され た後, 前処理設備である破砕選別装置によって, メタン 発酵に適した選別ごみと発酵不適物である選別残椬に分 けられる。選別ごみは，バイオマス設備用ごみピットな どを経てメタン発酵槽へ送られる。一方, 選別残椬は, バイオガス回収後の発酵残渣やリサイクルセンターから の可燃残椬とともに，熱回収設備用ごみピットを経て焼 却設備にて適正に処理される。また, メタン発酵槽から 発生する排水は, 熱回収設備のガス泠却室にてガス減温
水として利用される。

\section{5. 破砕選別装置と選別ごみ}

本施設では, 異物混入の許容範囲が広い乾式メタン発 酵方式を採用しているため, 厨芥類等の分別収集や複雑 な前処理システムを必要としない。困 5 の処理フローで示 したように, 前処理設備としては, 破砕装置による粗破砕 と破砕選別装置による選別との組み合せを採用している。

破砕選別装置では，破砕と同時に装置下部に設置した スクリーンによって, 粒径が小さい㕑芥類や紙類を回収 する。一方, 破砕されないプラスチック類や布類はスク リーンを通過せずに発酵不適物, 選別残椬として回収さ れ，熱回収設備用ごみピットに送られる。

図 6 に, ごみ種（厨芥類, 紙類, ビニール類, 布類)

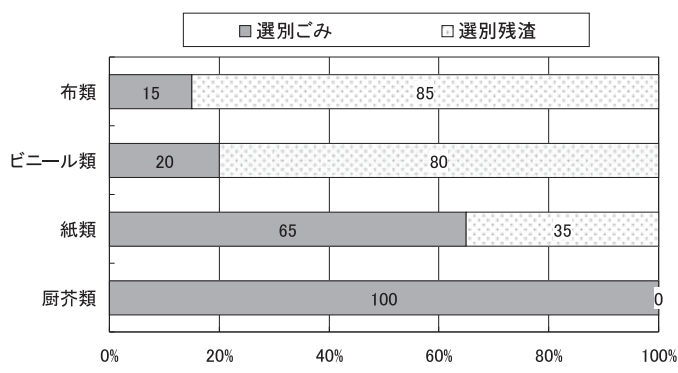

図 6 ごみ種ごとの選別比率

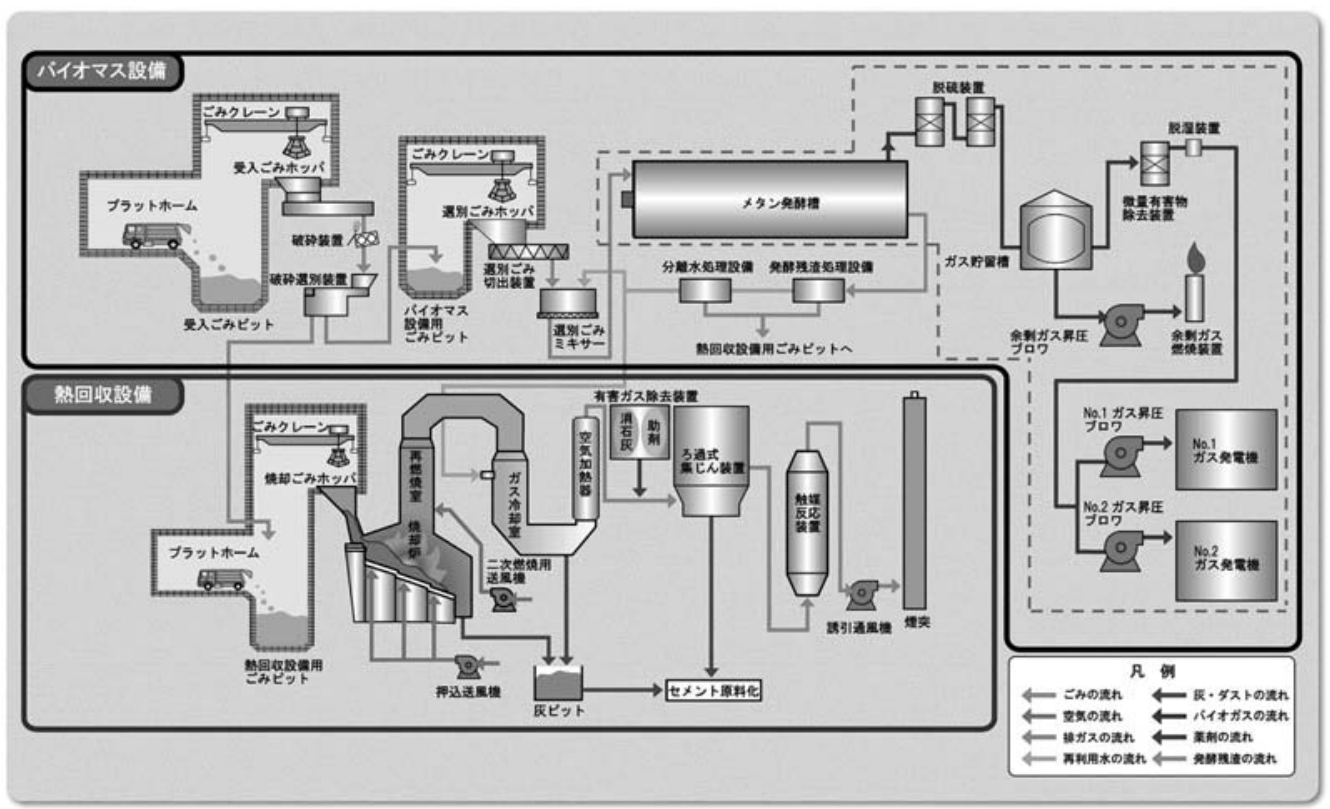

図 5 高効率原燃料回収施設の処理フロー図 


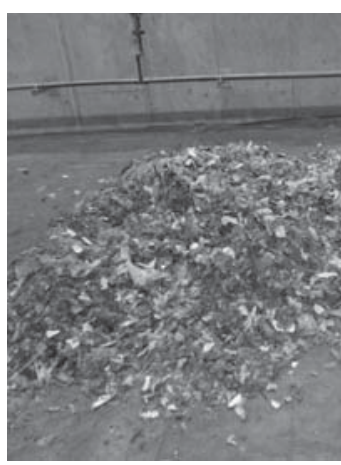

(a) 選別ごみ

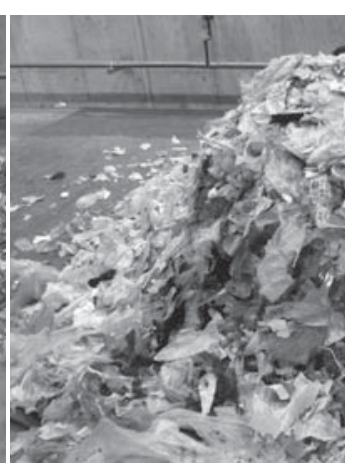

(b) 選別残椬
図 7 選別ごみと選別残椬の外観

ごとの選別ごみと選別残渣の比率を示す。厨芥類は安定 して破砕粒度が細かいので, 選別ごみの比率が 100\% と なっている。紙類は湿ったものは比較的細くなるが, 乾 いたものは粗い破䂗粒度になる傾向があるため, $65 \%$ が選別ごみとして回収されている。ビニール類や布・皮 革類は破砕粒度が粗くなるため, 選別ごみには 15〜 20\%しか含まれていない。図 7 に選別ごみと選別残渣 の写真を示す。図 6 に示した選別比率の顕著な傾向が見 かけ上にも鮮明に反映されており, 破砕選別装置の有効 性を表した結果となっている。

図 8 には, 選別ごみの三成分（可燃分，灰分，水分）

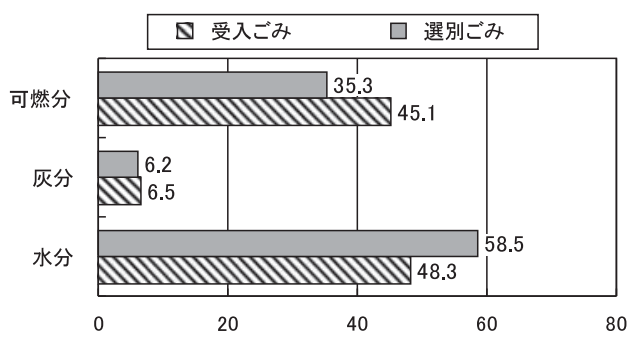

(a) 三成分 (\%)
と低位発熱量の分析例を示している。三成分では，受入 ごみに比べ㴻芥類や湿った紙類の割合が増加したことに より，選別ごみの水分が高くなっていて，それだけ可燃 分の割合が低下している。また，選別ごみの低位発熱量 をみると, 水分が高くなったことにより受入ごみに比べ て低下し, 選別残渣ではプラスチック類などの割合が増 加したため, 受入ごみと比べるとかなり高い值となって いる。

\section{6. メタン発酵設備}

選別ごみはミキサーで水分調整された後, バイオガス 原料としてメタン発酵槽へ送られる。メタン発酵槽は, 横置円筒型, 寸法: 直径 $6.4 \mathrm{~m} \times$ 長さ $32 \mathrm{~m}$, 有効容量 $875 \mathrm{~m}^{3}$ の仕様で, 概略図は図 9 に示すとおりである。 発酵槽は横型で水平方向の押出し流れとなっているため 特別な移動機構を必要とせず, 低速攪拌によるガス抜 きを行う程度でバイオガスが得られるため, 必要とする 動力が小さいという特長がある。メタン発酵槽で発生し たバイオガスは, ガスエンジン発電機（最大出力 382 $\mathrm{kW})$ による発電に利用され, さらにガスエンジンの廃 熱をメタン発酵槽の加温に用いている。

なお, 前処理設備を含むバイオマス設備における処理 不適物には次のようなものがあげられ, これらの混入に は注意を払う必要がある。

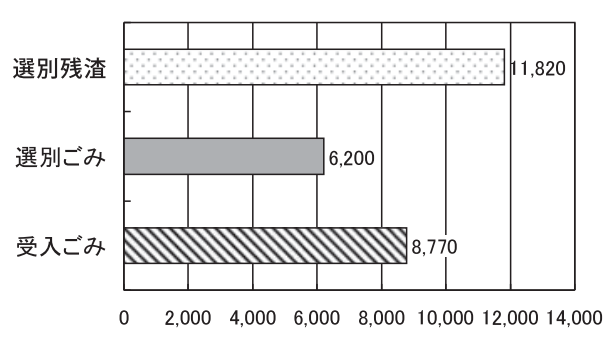

(b) 低位発熱量 $(\mathrm{kJ} / \mathrm{kg})$

図 8 選別ごみ等の組成と低位発熱量

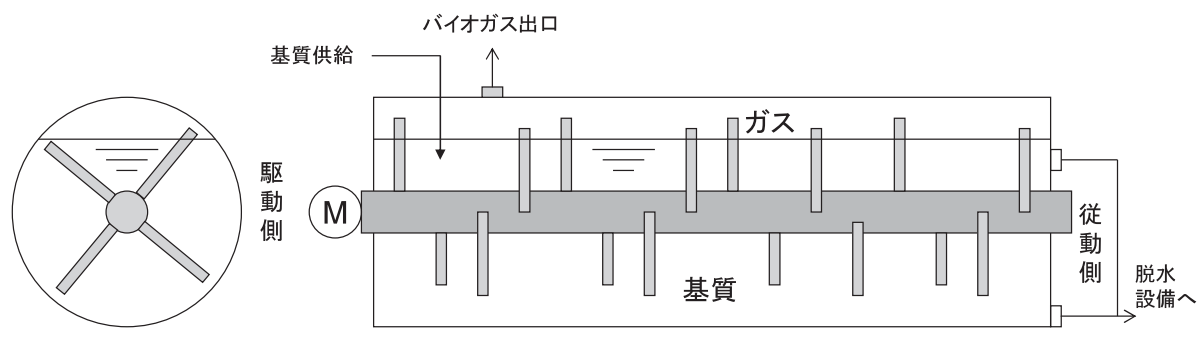

図 9 メ夕ン発酵槽 
（1）破 砕 不適 物：金属塊, 土砂類, 分厚い雑誌, 小型家電, 大型木製品

（2）破砕選別不適物：長尺の布類，ロープ類，長い 針金

（3）メタン発酵不適物：土砂類, 金属, ガラス・陶器類

（4）発酵 阻害物: 殺虫剤, 農薬, 強酸・強アル カリ廃液

\section{7. 施設全体の物質収支と電力収支}

\section{1 物質収支}

図 10 に高効率原燃料回収施設の物質収支の一例を示 す。バイオマス設備には, 家庭系収集可燃ごみと事業系 収集可燃ごみを合わせて 29.4 ton/日搬入され，熱回収 設備には，事業系収集可燃ごみ，可燃性粗大ごみ（リサ イクルセンターの可燃残椬), および持达可燃ごみ合計 で 15.8 ton/日が搬入される。図中の（ )内に示す数值は, 搬入ごみ全体 45.2 ton/日を $100 \%$ としたときの重量割合 である。

バイオマス設備（前処理設備）で選別ごみ 20.2 ton/ 日と選別残椬 9.2 ton/日に分けられる。メタン発酵槽で は，選別ごみと残渣脱水設備からの調湿水の合計量 42.1 ton/日によりバイオガスが $3,620 \mathrm{~m}^{3}{ }_{\mathrm{N}} \mathrm{dry} /$ 日発生し，ガ スエンジン発電設備にて $6,080 \mathrm{kWh} /$ 日の発電を行って いる。バイオガス発生量 $3,620 \mathrm{~m}^{3}{ }_{\mathrm{N}}-\mathrm{dry} /$ 日をメタン濃 度 $50 \%$ に換算し原料 20.2 ton/日で除すると，ごみ ton

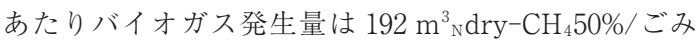
ton となる。また, 熱回収設備には, 搬入ごみに加えて 選別残渣 $9.2 \mathrm{ton} /$ 日, 残椬脱水設備から発酵残椬 11.9 ton/日が送られ，合計で 36.9 ton/日が処理されている。

\section{2 電力収支}

図 11 に高効率原燃料回収施設の電力収支を簡単に示 す。バイオマス設備（前処理設備等）および熱回収設備 における消費電力, いわゆる所内所要電力は 9,570 $\mathrm{kWh} /$ 日である。一方, バイオマス発電施設での発電量 は $6,080 \mathrm{kWh} /$ 日であり, 認定発電設備に係る消費電力 が 1,320 kWh/日となる。その結果, 外部への送電量が $4,760 \mathrm{kWh} /$ 日となり, この送電量がFIT の対象となる。

\section{8. おわりに}

従来, 発電が困難であった小規模ごみ処理施設におけ るバイオマスエネルギー利活用の先進的なモデル事例と して, 南但広域行政事務組合の実績について紹介した。 施設建設までの経緯, FITへの対応に始まり，施設概 要や物質収支などを報告した。

機械式破砕選別方式を採用したバイオガス化と燒却の コンバインドシステムの先駆けであり, FIT 活用の観 点からも大きな注目を集めており, 施設では見学申达が 絶えず職員は対応に追われる毎日を送っている。廃棄物

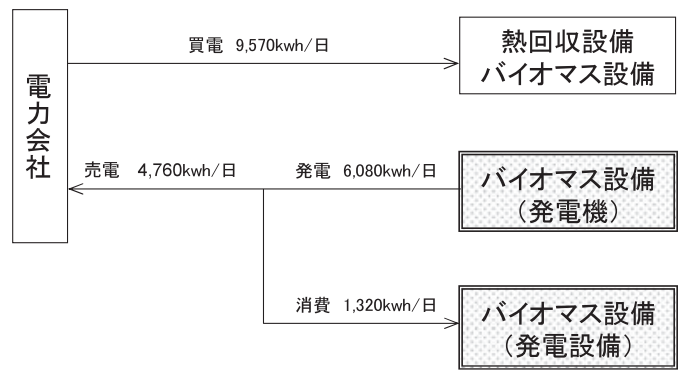

図 11 施設全体の電力収支の一例

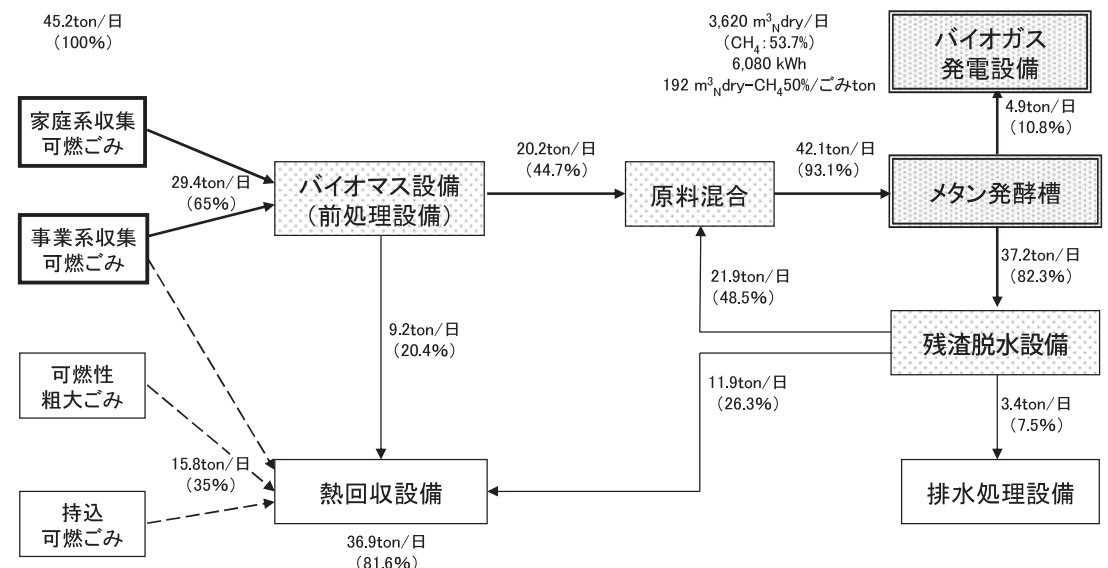

図 10 施設全体の物質収支の一例 
系バイオマスの利活用による循環型社会形成や地球温暖 化防止に資する重要なインフラであり, 今後, 実績を重 ね多方面に情報発信しながら努力を続けていきたい。

\section{参考文 献}

1) 南但広域行政事務組合

http : //www.nantan.hyogo.jp/html/kumiai_syoukai.h $\operatorname{tml}$ (閲覽日 2013 年 10 月 28 日）

2 ) 環境省 : 循環型社会形成交付金交付要綱

http : //www.env.go.jp/recycle/waste/3r_network/2_ koufu/koufu_youkou.pdf（閲覧日 2013 年 10 月 28 日）

3 ) 高岡好和, 藤田泰行, 永吉俊介: 高効率原燃料回収施 設の運転状況——南但クリーンセンター——, 都市 清掃，第 66 巻，第 316 号, pp. 568-571（2013）

\title{
Combined System Integrates Bio-gas Production Equipment and Waste Incineration in Nantan Area
}

\author{
Yoshikazu Takaoka*, Kohei Kawamura* and Yoshitada Kakuta** \\ * Integrated-administration Association of NANTAN Area \\ ** TAKUMA Co., Ltd. \\ † Correspondence should be addressed to Yoshitada Kakuta: \\ TAKUMA Co., Ltd. \\ (2-2-33 Kinrakuji, Amagasaki, Hyogo 660-0806 Japan)
}

\begin{abstract}
The Integrated-administration association of NANTAN is located in the Tajima district of northern Hyogo. The NANTAN facility was completed in May, 2013. It is an efficient materials-and-fuel recovery facility, which received the recycling-society promotion subsidy from the Ministry of Environment except for power generation equipment. The facility has a combined system that integrates biogas equipment run at a high temperature using dry-type methane fermentation and heat recovery equipment through incineration. This is first of its kind to be completed as a municipal facility in Japan. A special feature of the facility is that it does not require a separate collection of wastes by residents because a mechanical crushing/sorting system has been adopted for the pretreatment of wastes. Furthermore, the system is receiving great attention because the biogas equipment uses the electric power purchase system by Feed-in Tariff.

The NANTAN facility is an advanced model of biomass energy utilization for a small-scale waste treatment plant. This paper reports on the following features of the facility: circumstances surrounding facility construction, correspondence with FIT, facility outline, crushing/sorting device and characteristics of sorted waste, methane fermentation equipment, material balance and electric power balance.
\end{abstract}

Keywords : methane fermentation, Feed-in Tariff, crushing/sorting system, power generation, energy recovery 